GONÇALVES, LSA; GOMES, GP; DAMASCENO JUNIOR, CV; QUEIROZ, RA; TAKAHASHI, LSA; COSTA, DS; NUNES, MPBA. 2018. Seed physiological potential of "dedo-de-moça" pepper in relation to maturation stages and rest periods of the fruits. Horticultura Brasileira 36: 486-491. DOI - http://dx.doi.org/10.1590/S0102-053620180410

\title{
Seed physiological potential of "dedo-de-moça" pepper in relation to maturation stages and rest periods of the fruits
}

\author{
Leandro SA Gonçalves ${ }^{1}$; Gisely Paula Gomes ${ }^{1}$; Clério Valentin Damasceno Junior ${ }^{1}$; Robison Alessandro de \\ Queiroz $^{1}$; Lucia SA Takahashi' ${ }^{1}$; Denis S da Costa ${ }^{1}$; Maria PBA Nunes ${ }^{1}$
}

${ }^{1}$ Universidade Estadual de Londrina (UEL), Londrina-PR, Brazil; 1sagrural1@gmail.com; 1sagrural@yahoo.com.br; gipgomes@yahoo. com.br; clerio_jr@hotmail.com; luciasadayo@gmail.com; denisccauel@gmail.com; nunesmpb@yahoo.com.br

\begin{abstract}
One of the main problems in pepper seed production is the uneven maturation of the fruits due to the continuous flowering period of the plant, making it difficult to harvest all the fruits at the same time. Thus, studies on fruit maturation stage and seed physiological potential are extremely important in order to identify the appropriate harvest time, avoiding seed deterioration. The aim of this study was to evaluate the physiological potential of five genotypes of "dedo de moça" pepper seeds (Capsicum baccatum var. pendulum) in three maturation stages (green, orange and red), with and without 10-day rest period after harvest date. Physiological potential and vigor of seeds were evaluated through germination tests (first count, accelerated aging and electrical conductivity). The observed results were submitted to variance analysis, comparing averages through Tukey test and principal components analysis. In general, red fruits reflected seed maturity since they provided maximum germination. On the other hand, even fruits harvested at a maturation stage prior to red (green and orange), showed the benefits of the rest periods on germination and vigor characteristics, being this result more evident in green fruits which, initially, had lower physiological potential. The evaluated genotypes showed lower physiological potential of fruits harvested at the green stage, without 10-day rest period.
\end{abstract}

Keywords: Capsicum baccatum var. pendulum, accelerated aging, germination, vigor.

\section{RESUMO}

Potencial fisiológico de sementes de pimenta "dedo-de-moça" em função do estádio de maturação e do repouso dos frutos

Um dos principais problemas na produção de sementes de pimentas é a maturação desuniforme dos frutos. Isso ocorre devido ao florescimento contínuo da planta, dificultando que a colheita seja realizada de uma única vez. Dessa forma, estudos sobre o estádio de maturação dos frutos e o potencial fisiológico das sementes são de grande relevância para se identificar o momento adequado de colheita evitando a deterioração das sementes. O presente trabalho teve como objetivo avaliar o potencial fisiológico de sementes de pimenta de cinco genótipos de "dedo-de-moça" (Capsicum baccatum var. pendulum) em três estádios de maturação (verde, alaranjado e vermelho), sem e com repouso de 10 dias dos frutos a partir da colheita. As avaliações foram realizadas quanto ao potencial fisiológico representado pelos testes de germinação e vigor (primeira contagem, condutividade elétrica e envelhecimento acelerado). Os resultados observados foram submetidos à análise de variância e as médias comparadas pelo teste de Tukey, bem como à análise de componentes principais. De modo geral, a coloração vermelha dos frutos refletiu a maturidade das sementes por proporcionar a máxima germinação. Por outro lado, mesmo que os frutos sejam colhidos em estádio de maturação anterior ao vermelho (verde e alaranjado) o período de repouso mostrou-se benéfico para características de germinação e vigor, sendo este resultado mais evidente nos frutos verdes que inicialmente possuíam potencial fisiológico inferior. Os genótipos avaliados apresentaram potencial fisiológico inferior quando tiveram seus frutos colhidos verdes sem o repouso por 10 dias.

Palavras-chave: Capsicum baccatum var. pendulum, envelhecimento acelerado, germinação, vigor.

\section{Received on June 12, 2017; accepted on June 22, 2018}

$\mathrm{T}_{\mathrm{d}}^{\mathrm{h}}$ he genus Capsicum is a vegetable dedicated to fresh consumption and condiments, spices and preserved products (Moreira et al., 2013). Based on floral characteristics, such as shape of the calyx, color of the chorolla and number and orientation of flowers per node, this genus is classified into 38 species (USDA, 2011), considering that only five are considered domesticated:
C. annuum, C. frutescens, $C$. chinense, C. pubescens and C. baccatum (DeWitt \& Bosland, 2009).

The species $C$. baccatum is one of the main peppers grown in Brazil by family farmers (Villela et al., 2014). Among the different types of peppers belonging to this species, "dedo-demoça", also known as "chifre-deveado", "red pepper" and "Calabrian pepper" is one of the most used in Brazilian cuisine due to its sensorial quality (color, flavor and pungency). This pepper is widely consumed both in natura as well as processed, in the form of sauces and dehydrated (Carvalho et al., 2009; Cardoso et al., 2018).

Although "dedo-de-moça" pepper is a vegetable of great acceptance in the Brazilian market, only four cultivars 
are available for commercialization (MAPA, 2016). According to Justino et al. (2015), the lack of interest of seed producing companies to develop new Capsicum spp. cultivars is related to deficiencies in production techniques, low yield, difficulty of extraction and problems related to seed physiological potential.

The uneven fruit ripening, resulting from plant continuous flowering is one of the main problems in production of Capsicum spp. seeds, since this makes it difficult to harvest the fruits at the same time. Thus, the knowledge about the relationship fruit ripening and seed ripening is of great relevance, since it determines the appropriate harvest time, avoiding lots of immature seeds or under advanced deterioration process. In this context, several studies have been carried out in order to determine the ripening process of pepper seeds and identify the appropriate time for harvest, which results in production of high-quality seeds (Queiroz et al., 2011; Vidigal et al., 2011; Abud et al., 2013; Pereira et al., 2014; Justino et al., 2015).

In addition to studies on maturation and harvest time, other researchers point out that seeds kept inside the fruit after harvest, for some time, continue the maturation process, reaching high levels of germination and vigor (Vidigal et al., 2009; Ricci et al., 2013). For "dedode-moça" pepper, Pereira et al. (2014), evaluating fruits in four maturation stages [15, 25, 35 and 45 days after anthesis (DAA)] and submitted to rest period for 0,5 and 10 days, verified that the best germination results occurred at 45 DAA and that post-harvest rest period for 10 days improved seed physiological potential. On the other hand, Justino et al. (2015), evaluating seven ripening stages $(20,30,40,50,60,70$ and 80 DAA) verified that seed physiological potential occurred at 70 DAA, when the fruits showed red color. Thus, the authors verified differences in results for ripening of "dedo-de-moça" pepper, and this fact may be the cause of genotypic or environmental variation.

Thus, in this study we aimed to evaluate seed physiological potential of "dedo-de-moça" pepper (Capsicum baccatum var. pendulum) in three maturation stages (green, orange and red), without and with 10-day of postharvest rest period.

\section{MATERIAL AND METHODS}

"Dedo-de-moça" pepper fruits were harvested on May, 2015, from 60 plants grown in a greenhouse at Centro de Ciências Agrárias from Universidade Estadual de Londrina (UEL), Londrina, Paraná, Brazil $\left(23^{\circ} 22^{\prime} \mathrm{S}, 51^{\circ} 10^{\prime} \mathrm{W}\right.$; altitude $585 \mathrm{~m}$ ). Five genotypes were used, being three commercial cultivars (Horticeres, Hortivale and BRS Mari) and two accessions from the germplasm bank of UEL (UEL 110 and UEL 111).

During flowering phase, pepper flowers were dated daily, and from anthesis, up to obtain from 40 to 60 fruits of each genotype. At harvest, fruits were removed from plants based on their coloration and classified as green [unripe fruits, 48 to 53 days after anthesis (DAA)], orange (intermediate, 58 to 63 DAA) and red (ripe fruits, 67 to 72 DAA).

Seeds were extracted manually, from one part of harvested fruits, right after harvest, washed in running water and kept for drying for approximately 48 hours under monitored closed environmental conditions $\left(25 \pm 2^{\circ} \mathrm{C}\right)$. The remaining fruits were kept at rest for 10 days under $25^{\circ} \mathrm{C}$ temperature and $71 \%$ relative humidity, and then, the seeds were extracted manually, washed in water and dried under similar conditions to ones described previously.

The experiment was carried out in a completely randomized design in a factorial scheme $3 \times 2 \times 5$, being three maturation stages (green, orange and red), two rest periods of the fruits (postharvest extraction or after 10 days) and five genotypes, with four replicates.

Seeds were submitted to tests to determine the degree of moisture, germination and vigor (first count, accelerated aging and electrical conductivity). Germination test was conducted in four replicates and 50 seeds per treatment distributed on two germitest paper sheets, moistened with $0.2 \%$ potassium nitrate solution $\left(\mathrm{KNO}_{3}\right)$ equivalent to 2.5 times the dry paper mass, in Gerbox-type plastic boxes $(11 \times 11 \times 3.5 \mathrm{~cm})$. The samples were kept in a germination chamber at $30^{\circ} \mathrm{C}$ temperature and two evaluations were performed: the first called first germination count at day 8 and the second at day 14 after sowing. The normal seedling criterion was adopted according to criteria established by the Rules for Seed Analysis (RAS) and the results expressed in percentage (Brasil, 2009).

Accelerated aging test was installed distributing $1.0 \mathrm{~g}$ of single-layer seeds onto a stainless steel mesh tray coupled with Gerbox-type plastic boxes $(11 \times 11 \times 3,5 \mathrm{~cm})$, containing $40 \mathrm{~mL}$ distilled water. The seeds were kept in an incubator at $42^{\circ} \mathrm{C}$ for 96 hours (AOSA, 1983). Right after, the seeds were placed to germinate and on the $8^{\text {th }}$ day evaluated; the results were expressed in percentage of normal seedlings (Baalbaki et al., 2009).

For electrical conductivity test, the authors used four replicates of 50 seeds. These seeds were immersed in 25 $\mathrm{mL}$ distilled water and kept in a BOD incubator at $25^{\circ} \mathrm{C}$ for 48 hours; using a portable digital conductivity meter (model HI98300, Hanna), the electrical conductivity of the imbibition solution was determined. Results were expressed

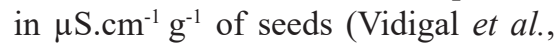
2008).

The obtained data were tested for normality and homogeneity of variances by the Shapiro-Wilk and Bartlett tests, respectively. Germination and first count variables were transformed by

$$
\arcsin \sqrt{\frac{x}{100}}
$$

to meet the assumptions of the analysis of variance. Afterwards, data were submitted to variance analysis and averages compared using Tukey test at $5 \%$. Principal components analysis was also used as database. All analyses were done with the aid of program R (http:// www.r-project.org) using package ExpDes (Ferreira et al., 2014) and FactoMineR (Lê et al., 2008).

\section{RESULTS AND DISCUSSION}

Using variance analysis, the authors 
observed a significant effect for variation sources: rest periods of the fruits (R), maturation stage (EM) and genotypes (G) for the most evaluated variables. A significant effect was observed for all variables, evaluating interactions between R x EM and EM x G showing differentiated behavior concerning rest period and maturation stages and also from genotypes and change in fruit maturity stage. For interactions $\mathrm{R} \times \mathrm{G}$ and EM x R x G, the authors verified a significant effect only for accelerated aging (ENV) and electrical conductivity (COND). These results show existence of genotypic variability regarding the types of treatments proposed to evaluate maturation and rest period of the pepper fruits. Coefficients of variation were 11.62, 17.87, 8.39 and 14.15\% for germination, first count, ENV and COND, respectively.

For germination and first count, higher values of post-harvest extraction were obtained from red fruits with 94 and $89 \%$ germination, respectively, whereas for fruits under 10-day rest, no differences were observed for the three fruit maturity stages (Table 1). On the other hand, the authors verified significant increase in germination and in the first count, after 10-day rest period, for seeds extracted from green and orange fruits, showing that in this

Table 1. Average values of germination (\%) and first germination count (\%) of C. baccatum var. pendulum seeds, "dedo-de-moça" type, extracted from fruits after 10-day rest period, in three maturity stages (green, orange and red). Londrina, UEL, 2016.

\begin{tabular}{lccc}
\hline \multirow{2}{*}{ Treatments } & \multicolumn{3}{c}{ Maturation stages } \\
\cline { 2 - 4 } & Green & Orange & Red \\
\hline Post-harvest extraction & $22 \mathrm{Cb}$ & Germination (\%) \\
10-day rest period of fruits & $93 \mathrm{Aa}$ & $76 \mathrm{Bb}$ & $94 \mathrm{Aa}$ \\
\hline & & First count (\%) & $94 \mathrm{Aa}$ \\
\hline Post-harvest extraction & $17 \mathrm{Cb}$ & $59 \mathrm{Bb}$ & $89 \mathrm{Aa}$ \\
10-day rest period of fruits & $90 \mathrm{Aa}$ & $96 \mathrm{Aa}$ & $89 \mathrm{Aa}$ \\
\hline
\end{tabular}

Averages followed by same uppercase letter in line and lowercase letter in column do not differ by Tukey test $(\mathrm{p}<0.5)$.

Table 2. Seed germination and first germination count of five C. baccatum var. pendulum, "dedo-de-moça" type genotypes, extracted from fruits in three maturity stages (green, orange and red). Londrina, UEL, 2016.

\begin{tabular}{llcl}
\hline \multirow{2}{*}{ Genotypes } & \multicolumn{3}{c}{ Maturation stages } \\
\cline { 2 - 4 } & Green & Orange & Red \\
\hline UEL111 & $53 \mathrm{Bbc}$ & $91 \mathrm{Aa}$ & $96 \mathrm{Aa}$ \\
UEL110 & $44 \mathrm{Bc}$ & $86 \mathrm{Aa}$ & $97 \mathrm{Aa}$ \\
BRS Mari & $68 \mathrm{Ba}$ & $84 \mathrm{ABa}$ & $94 \mathrm{Aa}$ \\
Horticeres & $61 \mathrm{Bab}$ & $67 \mathrm{Bb}$ & $93 \mathrm{Aa}$ \\
Hortivale & $66 \mathrm{Bab}$ & $93 \mathrm{Aa}$ & $98 \mathrm{Aa}$ \\
\hline & & First count (\%) \\
\hline UEL111 & $50 \mathrm{Bab}$ & $90 \mathrm{Aa}$ \\
UEL110 & $40 \mathrm{Bb}$ & $82 \mathrm{Aa}$ & $96 \mathrm{Aa}$ \\
BRS Mari & $62 \mathrm{Bab}$ & $75 \mathrm{ABab}$ & $95 \mathrm{Aa}$ \\
Horticeres & $49 \mathrm{Bab}$ & $55 \mathrm{Bb}$ & $93 \mathrm{Aa}$ \\
Hortivale & $65 \mathrm{Ba}$ & $85 \mathrm{ABa}$ & $96 \mathrm{Aa}$ \\
\hline
\end{tabular}

Averages followed by same uppercase letter in line and lowercase letter in column do not differ by Tukey test $(\mathrm{p}<0.05)$. period the seeds had completed their maturation process (Table 1).

Post-harvest extraction from green and orange fruits interrupts the seed maturation process resulting in seeds with low physiological potential. However, the seeds remaining inside the fruits for 10 days allowed its complete maturation. Similar results were observed by Pereira et al. (2014) for "dedo-de-moça" pepper harvested in different maturation stages and stored for 0,5 and 10 days; The 5 and 10-day postharvest storage provided an increase in seed germination. For bell pepper, another species of genus Capsicum, Teixeira et al. (2006) observed that the seeds extracted from yellowish green fruits, without storage, showed $40 \%$ and $90 \%$ germination after zero and seven-day storage, repectively. Thus, the results obtained in this study confirmed that early-harvested fruits, resting for some days, result in better physiological potential.

Genotypical effect was verified using interaction $\mathrm{EM} \times \mathrm{G}$, for germination and first count, in which no differentiation of genotypes in red fruit stage was observed (Table 2). However, for green fruits, higher values were obtained for genotypes BRS Mari, Horticeres and Hortivale, whereas for orange color, higher values were observed for genotypes UEL111, UEL110, BRS Mari and Hortivale.

Some studies have shown some variability in germination and vigor of seeds in accessions belonging to same species, such as for passion fruit (Freitas, 2009), papaya (Cardoso et al., 2009) and Capsicum spp. (Pessoa et al., 2015). Pessoa et al. (2015), evaluating $\mathrm{F}_{2}$ population of $C$. annuum, verified variability and high heritability for variables related to seed physiological potential, considering that these characteristics can be used in the first generations of selection aiming to obtain uniformity of emergency and seedling vigor.

For accelerated aging test, the genotypes Hortivale, Horticeres and UEL 111 obtained the highest values when evaluated at red maturation stage, without 10-day rest, whereas for fruits at orange stage, the highest values were 
verified for genotypes UEL 111 and Hortivale (Table 3). Fruits submitted to a 10-day rest period, except for green maturation stage, did not present any difference between genotypes at red and orange stage. Among the green fruits the highest values were observed for BRS Mari and Hortivale.

For post-harvest extraction, the highest values for accelerated aging were observed at red maturation stage for UEL 111, Horticeres and Hortivale, whereas for UEL 111 and UEL 110 no difference at orange and red maturation stages was verified. Comparing genotypes in relation to maturity stages of fruits under a 10-day rest period, UEL 110 and Horticeres obtained higher number of normal seedlings after accelerated aging for orange maturation

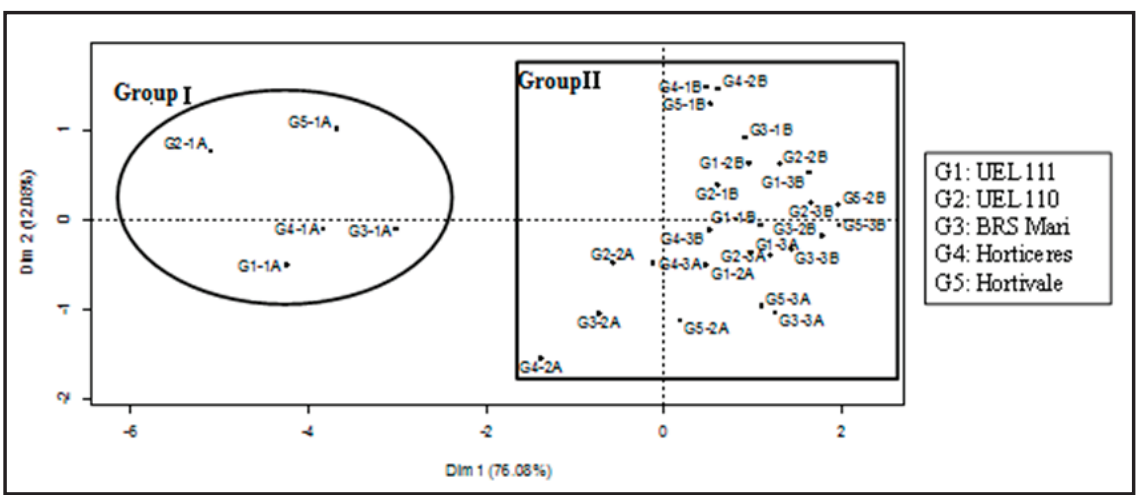

Figure 1. Biplot raph of Principal Component Analysis of pepper genotypes C. baccatum var. pendulum. Green fruits without rest (1A); green fruits with rest (1B); intermediate-colored fruits without rest (2A); orange fruits with rest (2B); red fruits without rest (3A); red fruits with rest (3B). Londrina, UEL, 2016. stage compared to green fruits (Table 3 ). Contrarily, no difference for orange and red maturation stages for fruits under rest period was noticed.

Comparing post-harvest extraction and 10-day rest period of the fruits, the authors observed higher values for accelerated aging in post-harvest rest period of green fruit stage, for all genotypes; orange stage fruits showed the same results, except for the genotype UEL 111. Red fruits presented a difference between post-harvest extraction and 10-day rest period only for genotypes UEL 110 and BRS Mari which obtained higher values when the fruits were in rest period. Queiroz et al. (2011), evaluating accelerated aging of Habanero Yellow pepper, verified that maximum vigor was noticed for seeds harvested at 67 DAA, 7 days of storage (rest period). This study corroborates the results in this research, in which the authors observed that 10-day rest of fruits resulted in more vigorous seeds, considering this result more evident in green fruits which initially showed lower physiological potential (Table 3).

For electrical conductivity lower values for orange and red stages for post-harvest extraction were observed (Table 3). For fruits under a 10-day rest, no differences among maturation stages for genotypes BRS Mari and Hortivale were observed, whereas in relation to other genotypes better results were obtained for orange and red stages. Comparing presence or absence of rest period of fruits for 10 days, differences for the three fruit maturity stages were noticed, considering that higher values were observed for postharvest extraction. For green fruits, the authors observed differences for genotypes UEL 110, BRS Mari and Hortivale, whereas for orange fruits, the authors observed differences for UEL 111, BRS Mari and Hortivale. For red fruits, the difference mentioned above was observed only for genotypes UEL 110 and Hortivale, showing existence of genotypic variability among the genotypes regarding the rest period in the three maturation stages. In relation to genotypes, BRS Mari obtained the lowest values for the three post-harvest maturation stages, whereas in 10-day

Table 3. Accelerated aging test and electrical conductivity from seeds of five C. baccatum var. pendulum "dedo-de-moça" type genotypes, post-harvest extracted and after 10-day rest period of fruits in three maturity stages (green, orange and red). Londrina, UEL, 2016.

\begin{tabular}{|c|c|c|c|c|c|c|}
\hline \multirow{2}{*}{ Genotypes } & \multicolumn{3}{|c|}{ Post-harvest extraction } & \multicolumn{3}{|c|}{ 10-day rest period } \\
\hline & Green & Orange & Red & Green & Orange & Red \\
\hline UEL 111 & $4 \mathrm{Bc}$ & $77 \mathrm{Aa}$ & $75 \mathrm{Aab}$ & $61 \mathrm{Bb}^{*}$ & $74 \mathrm{Aba}$ & $82 \mathrm{Aa}$ \\
\hline UEL 110 & $31 \mathrm{Ba}$ & $55 \mathrm{Abc}$ & $56 \mathrm{Ac}$ & 71Bab* & $88 \mathrm{Aa}^{*}$ & $90 \mathrm{Aa}^{*}$ \\
\hline BRS Mary & $24 \mathrm{Bba}$ & $36 \mathrm{Bd}$ & $64 \mathrm{Abc}$ & $85 \mathrm{Aa}^{*}$ & $88 \mathrm{Aa}^{*}$ & $90 \mathrm{Aa}^{*}$ \\
\hline Horticeres & $15 \mathrm{Cb}$ & $48 \mathrm{Bcd}$ & $84 \mathrm{Aa}$ & $66 \mathrm{Bb}^{*}$ & $84 \mathrm{Aa}^{*}$ & $85 \mathrm{Aa}$ \\
\hline \multirow[t]{2}{*}{ Hortivale } & $24 \mathrm{Cab}$ & $70 \mathrm{Bab}$ & $87 \mathrm{Aa}$ & $86 \mathrm{Aa}^{*}$ & $87 \mathrm{Aa}^{*}$ & $89 \mathrm{Aa}$ \\
\hline & \multicolumn{6}{|c|}{ Electrical conductivity $\left(\mu \mathrm{S} \mathrm{cm}^{-1} \mathrm{~g}^{-1}\right.$ seeds) } \\
\hline UEL 111 & $1.66 \mathrm{Ac}$ & $0.99 \mathrm{Bc}^{*}$ & $1.00 \mathrm{Bab}$ & $1.10 \mathrm{Ab}$ & $0.75 \mathrm{Bc}$ & $0.95 \mathrm{ABb}$ \\
\hline UEL 110 & $4.53 \mathrm{Aa}^{*}$ & $1.01 \mathrm{Bc}$ & $1.15 \mathrm{Bab}^{*}$ & $1.13 \mathrm{Ab}$ & $1.09 \mathrm{Aa}$ & $0.88 \mathrm{Bb}$ \\
\hline BRS Mary & $2.07 \mathrm{Ac}^{*}$ & $0.64 \mathrm{Bd}^{*}$ & $0.88 \mathrm{Bb}$ & $0.42 \mathrm{Ac}$ & $0.39 \mathrm{Ad}$ & $0.73 \mathrm{Abc}$ \\
\hline Horticeres & $2.30 \mathrm{Ac}$ & $1.82 \mathrm{Ab}$ & $1.30 \mathrm{Ba}$ & $2.34 \mathrm{Aa}$ & $1.77 \mathrm{Bb}$ & $1.59 \mathrm{Ba}$ \\
\hline Hortivale & $3.87 \mathrm{Ab}^{*}$ & $2.64 \mathrm{Ba}^{*}$ & $1.08 \mathrm{Cab}^{*}$ & $0.58 \mathrm{Ac}$ & 0.57 Acd & $0.46 \mathrm{Ac}$ \\
\hline
\end{tabular}

${ }^{*}$ Differences between two seed extraction times (post-harvest and 10-day rest period). Averages followed by same uppercase letter in line and lower case letter in column do not differ by Tukey test $(\mathrm{p}<0.05)$. 
rest period, the lowest values were verified for genotypes BRS Mari and Hortivale.

Electrical conductivity test is related to the amount of leached ions, being directly related to cell membrane integrity (Vidigal et al. 2008). Thus, the higher the value of the electrical conductivity of the soaking solution, the more unstructured are the membranes. Thus, the results of electrical conductivity test corroborate accelerated aging test, since the highest values (more unstructured membranes) were observed for green fruits. The authors also noticed that 10-day rest period helps restructure cell membranes due to the lowest values observed in some situations after this rest period (Vieira et al., 2002). Similar results were found by Pereira et al. (2014) who verified reduction of electrical conductivity values as the fruits were ripening and also during their storage period, showing higher vigor of "dedode-moça" pepper seeds.

Using principal components analysis (ACP), the authors observed that two of the first components explained $88.16 \%$ of variation, considering that $\mathrm{CP} 1$ and $\mathrm{CP} 2$ described 76.1 and $12.1 \%$, respectively (Figure 1). According to Cruz \& Regazzi (2001), when the two first variables explain over $70 \%$ of total variation, their use is satisfactory in the multivariate study using dispersion graphic of scores in relation to the variables.

In the two-dimensional graphic dispersion of ACP, the authors could notice two big different groups: the first group defined by the genotypes with green fruits whose seeds were extracted after harvest, whereas the second group was composed of the other treatments (Figure 1A). In this sense, 10-day rest period of the green fruit in order to have their seeds extracted favors seed physiological potential, obtaining values close to the ones obtained with fruits harvested at orange and red stages.

Overall, fruit coloration reflected seed maturity since it provides maximum germination when red color was observed. On the other hand, even if the fruits are harvested at maturation stage before the red stage (green and orange) rest period will be beneficial for germination and vigor characteristics, showing similar behavior, with different intensities for each studied genotype, though. Thus, a practical application is the possibility of seed producers concentrate the harvest obtaining higher total quantities of fruits and that, through selection and rest period of green and orange fruits, could obtain lots of seeds with high physiological potential. Lastly, the authors highlight that the knowledge about behavioral maturation of the genotype results in greater efficiency for high-quality seed production since such different responses are observed. "Dedo-de-moça" genotypes showed lower physiological potential when their fruits were harvested at green stage without 10-day rest period.

\section{REFERENCES}

ABUD, HF; ARAUJO, EF; ARAUJO, RF; ARAUJO, AV; PINTO, CMF. 2013. Qualidade fisiológica de sementes das pimentas malagueta e biquinho durante a ontogênese. Pesquisa Agropecuária Brasileira 48: 1546-1554.

ASSOCIATION OF OFFICIAL SEED ANALYSTS. 1983. Seed vigor testing handbook. East Lansing: AOSA. 88p. (Contribution, 32).

BAALBAKI, RS; ELIAS, S; MARCOS-FILHO, J; McDONALD, MB. 2009. Seed vigor testing handbook. New York: AOSA. 346p.

BRASIL. Ministério da Agricultura, Pecuária e Abastecimento. 2009. Regras para análise de sementes. SDA. Brasilia: Mapa. 399p.

CARDOSO, DL; SILVA, RF; PEREIRA, MG; VIANA, AP; ARAÚJO, EF. 2009. Genetic diversity and genetic parameters related to physiological seed quality in papaya germplasm. Revista Ceres 56: 572-579.

CARDOSO, R; RUAS, CF; GIACOMIN, RM; RUAS, PM; RUAS, EA; BARBIERI, RL; RODRIGUES, R; GONÇALVES, LSA. 2018. Genetic variability in brazilian Capsicum baccatum germplasm collection assessed by morphological fruit traits and AFLP markers. Plos One 13: e0196468.

CARVALHO, SIC; RIBEIRO, CSC; HENZ, GP; REIFSCHNEIDER, FJB. 2009. BRS Mari: nova cultivar de pimenta dedo-de-moça para processamento. Horticultura Brasileira 27: 571-573.

CRUZ, CD; REGAZZI, AJ. 2001. Modelos biométricos aplicados ao melhoramento genético. Viçosa: UFV. 390p.

DEWITT, D; BOSLAND, PW. 2009. The complete chile pepper book. A gardener's guide to choosing, growing, preserving and cooking. Portland: Timber Press. 336p.

FERREIRA，EB; CAVALCANTI，PP;
NOGUEIRA, DA, 2014. ExpDes: An R package for anova and experimental designs. Applied Mathematics 5: 2952-2958.

FREITAS, MVS. 2009. Qualidade fisiológica das sementes e parâmetros genéticos de progênies de maracujazeiro amarelo (Passiflora edulis $\mathrm{f}$. flavicarpa). Rio de Janeiro: UENF. 52p. (MSc dissertation)

JUSTINO, EV; BOITEUX, LS; FONSECA, MEN; SILVA FILHO, JG; NASCIMENTO, WM. 2015. Determinação da maturidade fisiológica de sementes de pimenta dedo de moça Capsicum baccatum var. pendulum. Horticultura Brasileira 33: 324-33.

LÊ, S; JOSSE, J; HUSSON, F. 2008. Facto Miner: an r package for multivariate analysis. Journal of Statistical Software 25: 1-18.

MAPA. Ministério da Agricultura, Pecuária e Abastecimento. Accessed at August 15, 2016. Available http://www.agricultura.gov.br/

MOREIRA, SO; RODRIGUES, R; OLIVEIRA, HS; MEDEIROS, AM; SUDRÉ, CP; GONÇALVES, LS. 2013. Phenotypic and genotypic variation among Capsicum annuum recombinant inbred lines resistant to bacterial spot. Genetics and Molecular Research 12:1232-1242.

PEREIRA, FECB; TORRES, SB; SILVA, MIL; GRANGEIRO, LC; BENEDITO, CP. 2014. Qualidade fisiológica de sementes de pimenta em função da idade e do tempo de repouso pós-colheita dos frutos. Revista Ciência Agronômica 45:737-744.

PESSOA, AMS; BARROSO, PA; RÊGO, ER; MEDEIROS, GA; BRUNO, RLA; RÊGO, MM. 2015. Genetic divergence of physiological-quality traits of seeds in a population of peppers. Genetics and Molecular Research 14: 12479-12488.

QUEIROZ, LAF; PINHO, EVR; OLIVEIRA, JA; FERREIRA, VF; CARVALHO, BO; BUENO, ACR. 2011. Época de colheita e secagem na qualidade de sementes de pimenta habanero yellow. Revista Brasileira de Sementes 33: 472-481.

RICCI, N; PACHECO, AC; CONDE, AS; CUSTÓDIO, CC. 2013. Qualidade de sementes de pimenta jalapenho em função da maturação e tempo de permanência nos frutos. Pesquisa Agropecuária Tropical 43: 123-129.

TEIXEIRA, BA; NASCIMENTO, WM; FREITAS, RA. 2006. Maturação de sementes de pimentão 'Tico'. Horticultura Brasileira 24. Suplemento 1.

USDA - United States Department of Agriculture. Accessed January 14, 2011. Grin species records of Capsicum. Beltsville, Maryland: National Germplasm Resources Laboratory. Available at http://www.arsgrin.gov/cgi-bin/ npgs/html/exsplist.pl/

VIDIGAL, DS; DIAS, DCFS; DIAS, LAS; FINGER, FL. 2011. Changes in seed quality during fruit maturation of sweet pepper. Scientia Agricola 68: 535-539.

VIDIGAL, DS; DIAS, DCFS; PINHO, EVR; DIAS, LAS. 2009. Alterações fisiológicas e enzimáticas durante a maturação de sementes de pimenta (Capsicum annuum L.). Revista Brasileira de Sementes 31: 129-136.

VIDIGAL, DS; LIMA, JS; BHERING, MC; DIAS, DCFS. 2008. Teste de condutividade 
elétrica para sementes de pimenta. Revista Brasileira de Sementes 30: 168-174.

VIEIRA, RD; PENARIOL, AL; PERECIN, D; PANOBIANCO, M. 2002. Condutividade elétrica e teor de água inicial das sementes de soja. Pesquisa Agropecuária Brasileira 37: 1333-1338.

VILLELA, JCB; BARBIERI, RL; CASTRO, CM; NEITZKE, RS; VASCONCELOS, CS; CARBONARI, T; MISTURA, CC;
PRIORI, D. 2014. Caracterização molecular de pimentas crioulas (Capsicum baccatum) com marcadores microssatélites. Horticultura Brasileira 32: 131-137. 